\title{
STRATEGY FOR PREVENTING FOREST AND LAND FIRES IN BELITUNG REGENCY
}

\author{
Amallia Anggraini \\ Master program of Geography Education, Faculty of Social Science, Universitas Negeri Padang, \\ anggraini.amallia@gmail.com
}

\begin{abstract}
The purpose of this study is to determine the behavior of society and other parties in managing forests and land as well as to formulate strategies to prevent forest and land fire in Belitung Islands Belitung province. This study uses a mixed method by combining descriptive method which is supported by AHP (Analytical Hierarchy Process). From the analysis that has been done, there are five policy priorities that can be applied as the policy strategies to prevent both forest and land fires in Belitung Regency, namely: 1) imposition of discipline the use of fire for land expansion, 2) Tightening surveillance, patrols and surveillance in vulnerable forest burning, 3) Socialization and elucidation to the society about the dangers of forest and land fires, 4) Develop training patterns of forest and land fire prevention, 5) Establish prone areas to fire.
\end{abstract}

Keywords: Prevention Strategies, Forest, Fire

\section{Introduction}

Forest fire as one of the environmental problems that often occur on a large scale is one of the causes of forest degradation and prooven to cause damage and loss on the economic, ecological, and social aspect. The cause of the magnitude of the incidence of forest fires in Indonesia come from weak regulatory and enforcement of existing rules and not optimal mechanisms or institutional systems that handle forest fires 1 .

Causes of land and forest fires in Indonesia are generally caused by two factors. First, because of human negligence who are conducting their activities in the forest. Second, because the intentional factor, namely the human deliberate clearing land and plantations by burning. Forest fires due to human negligence is much smaller than the factor of deliberate burning forests. Land clearing by burning is done at the time of opening of new land or for replanting the forest industry in the region. Land clearance by burning will takes low cost, but clearly this way is irresponsible and raises a very big impact. The resulting losses are also very large. Forest fires causing damage to the environment. Forest fire smoke can interfere with public health and cause respiratory infectious diseases and the

\footnotetext{
${ }^{1}$ Syaufina, Lailan dan Fransisxo GS Tambunan. 2013. "Kearifan Lokal Masyarakat Adat dalam Pencegahan Kebakaran Hutan dan Lahan (Studi Kasus Masyarakat Adat Kasepuhan Ciptagelar Village of Sirnaresmi, Kecamatan Cisolok, District of Sukabumi, Provinsi Jawa Barat. "Jurnal Silvi kultur Tropika.
} 
effectiveness of transportation due to poor visibility ${ }^{2}$. Extensive forest fires can disrupt communities neighboring countries, and if not covered can lead to a negative assessment of the international community against the Indonesian government.

Sectoral impacts of these fires include the sectors of transport, health, economic, ecological and social, including the nation's image in the eyes of neighboring countries and the world ${ }^{3}$. Haze is the most visible sign that there will be a mistake in land management in the plantation sector and cannot be continued. The protection of peat land and forest is the best long-term solution to stop forest fires and prevent public health disaster in the future.

Causes of land and forest fires in Indonesia are generally caused by two factors. First, because of human negligence who are conducting activities in the forest. Second, because the intentional factor, namely the human deliberate clearing land and plantations by burning. Forest fires due to human negligence is much smaller than the intentional factor burn the forest. Land clearing by burning is done at the time of opening of new land or for replanting the forest industry in the region. Land clearance by burning will take low cost, but clearly this way is irresponsible and raises a very big impact. The resulting losses are also very large. Forest fires causing damage to the environment. Forest fire smoke can interfere with public health and cause respiratory infections (ispa) and the effectiveness of transportation due to poor visibility. Extensive forest fires can disrupt communities neighboring countries, and if not addressed can lead to a negative assessment of the international community against the government of Indonesia ${ }^{4}$.

Various efforts have been made by the government to prevent forest fires and land, including through the policy of opening the land without burning (zero burning policy). The policy was later reinforced by the Indonesian Government Regulation No. 4 of 2001 on Damage Control or Environmental Pollution related to Forest Fire and or land, Undang-undang 41 year 1999 about Forestry and Undang-undang No. 18 year 2004 on Plantations. But the fire still occur that is caused by the behavior of society and also the owner of the plantation companies in managing land to be used as farm land by burning forests. This is the condition that causes smog and cause disturbances in various facets of life, the increasing number of patients with respiratory infections (ISPA) because the air quality is unhealthy, many schools were closed when the haze is in a dangerous level, disruption of smoke can also occur on the means transportation / transport form of lower limit of view as well as other disasters.

\footnotetext{
${ }^{2}$ Bahri, Syamsul. 2002. "Kajian Penyebaran Kabut Asap Kebakaran Hutan dan Lahan di Wilayah Sumatera Bagian Utara dan Kemungkinan Mengatasinya dengan TMC". Jurnal Sains dan Teknologi Modifikasi Cuaca.

${ }^{3}$ Hermawan in Pasaribu, Sahat M. dan Supena Friyatno. 2006. "Memahami Penyebab Kebakaran Hutan dan Lahan serta Upaya Penanggulangannya: Kasus Di Provinsi Kalimantan Barat". Jurnal Kebijakan Pertanian. Pusat Analisis Sosial Ekonomi dan Kebijakan Pertanian. Badan Litbang Pertanian, Bogor.

${ }^{4}$ Bahri, Syamsul. 2002. Op cit.
} 
It has become a public concern, not only the people who live around the forest edge Sungai Sembilan, but also the national and international attention. Concerning this condition, it is needed a strategy for the prevention of forest and land fires in that area. The strategy can be applied either from the government or the society around the edge of the forest that is very necessary in the hope of clearing the land to be cultivated by society can be done without fuel, or at least the burning of land by well-controlled, and the emergence control of society itself in the prevention of forest fire.

\section{Method}

This research is mixed Method with descriptive method. Descriptive study conducted to assess the reality field in order to get an overview of the factual and accurate information on forest fire prevention strategies and land in the Belitung regency at Belitung province. Data collection techniques obtained by using inductive data analysis through interviews, observation and official documents of the agencies concerned on it. Analysis of the data used in this research is the analysis of primary data and secondary data, then proceed with the Indept interview, Focus Group dicussion (FGD), and then to determine the priority of the strategy to prevent forest fires and land in Belitung regency Belitung province performed using Analytical Hierarcy Process (AHP).

\section{Results and Discussion}

Belitung Regency is located between 107008 ' to 107058 BT and 02030 'to $03015 \mathrm{LS}$, with a land area of $2293.69 \mathrm{~km}^{2}$ and $6363 \mathrm{~km}^{2}$ area of the ocean. Belitung Regency consists of 5 sub-district, namely: District Membalong, District TanjungPandan, District Badau, Sijuk and District Nasik. Northern Belitung province bordering the South China Sea, East of Belitung Regency of East Belitung, South of Belitung province bordering the Java Sea, and the West Belitung Gaspar Strait.

Belitung Regency is a region that suffered environmental disasters, the environmental damage caused by land and forest fires. The cause of forest fires and land in Belitung Regency mostly caused by negligence tiller to prepare the land for farming, so the fire spread into forest areas. Impacts that is perceived by the society in Belitung due to forest fires and land are: reduced income due to loss of resources that are cultivated, tree mortality and reduced availability of water and declining water quality due to sedimentation from erosion in the burnt area and damage the soil.

In this case the role of government and the community are needed to reduce land and forest fires that occur. So it is necessary to formulate policy directives for the prevention of forest fires and land, through the roles of agencies, namely the role of Bappeda, Department of Forestry, Plantation Office, Department of Education, Office of Environment, Conservation of Natural Resources, the role of local communities edge of the woods, and cultivated lands and estates organizer, so that problems can be completed well. Model policies are offered related to 
forest fire prevention strategies and land can be analyzed using Analysis of Hierarchy Process or AHP.

Hierarchy policies can be seen in Figure 1, which in the picture explains that the policy direction of forest fire prevention strategies and land there are three criteria, namely: 1) law enforcement, 2) technical approach and 3) Role of education.

\section{Figure 1. Hierarchy of strategic direction to prevent forest fires and land and Consistency Value Ratio policy directives forest and land fire prevention strategies}

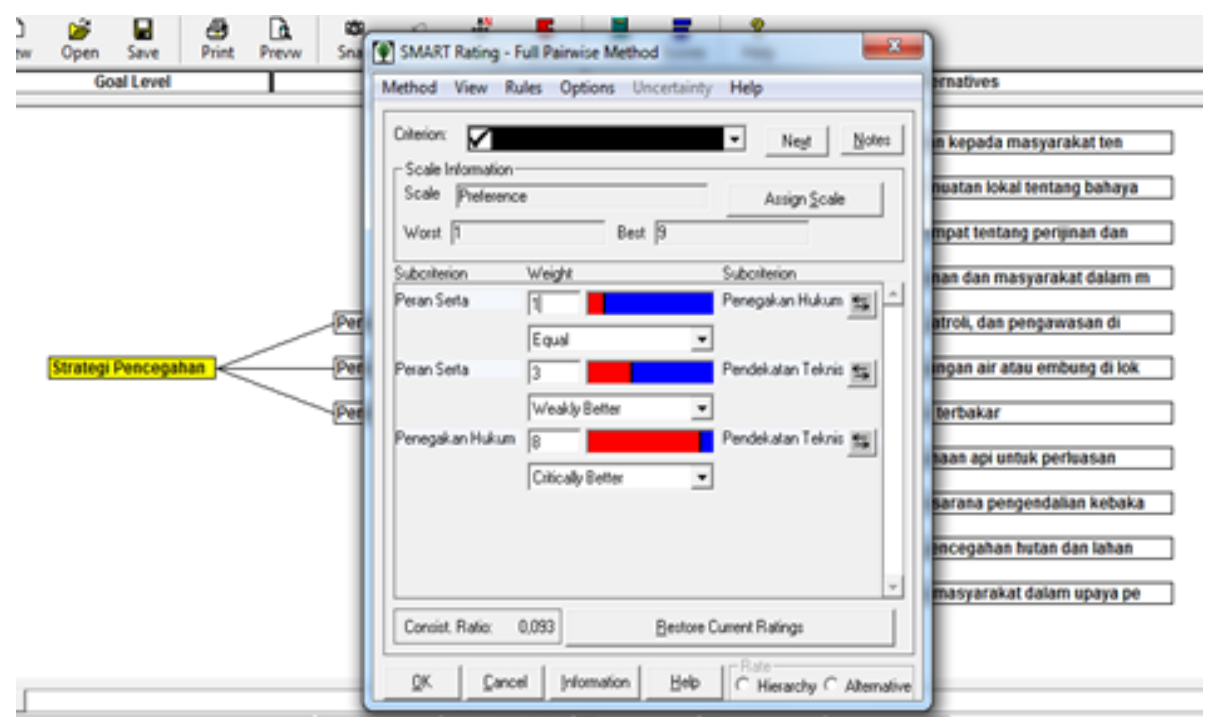

Based on that three criteria resulted in 10 policy alternatives, namely: 1) Socializing and elucidating to the society about the dangers of forest fires and land, 2) Adding a local curriculum on environmental sustainability-based forest and land fires, 3) Checking local regulations about licensing and restrictions ban combustion, 4) Cooperation forest officials and the society in fire prevention, 5) Tightening guard patrols and surveillance in vulnerable forest burned, 6) Creating a channel water reservoirs or ponds in locations prone to burning, 7) defining an area prone to burn, 8) disciplining the use of fire for land expansion, 9) procurement for control of land and forest fires, 10) weaving patterns prevention training land and forest fires, 11) enhancing public participation in preventing forest fires and land through institutional strengthening community Care fire (MPA ). 
Figure 2. Alternative policy directives forest and land fire prevention strategies

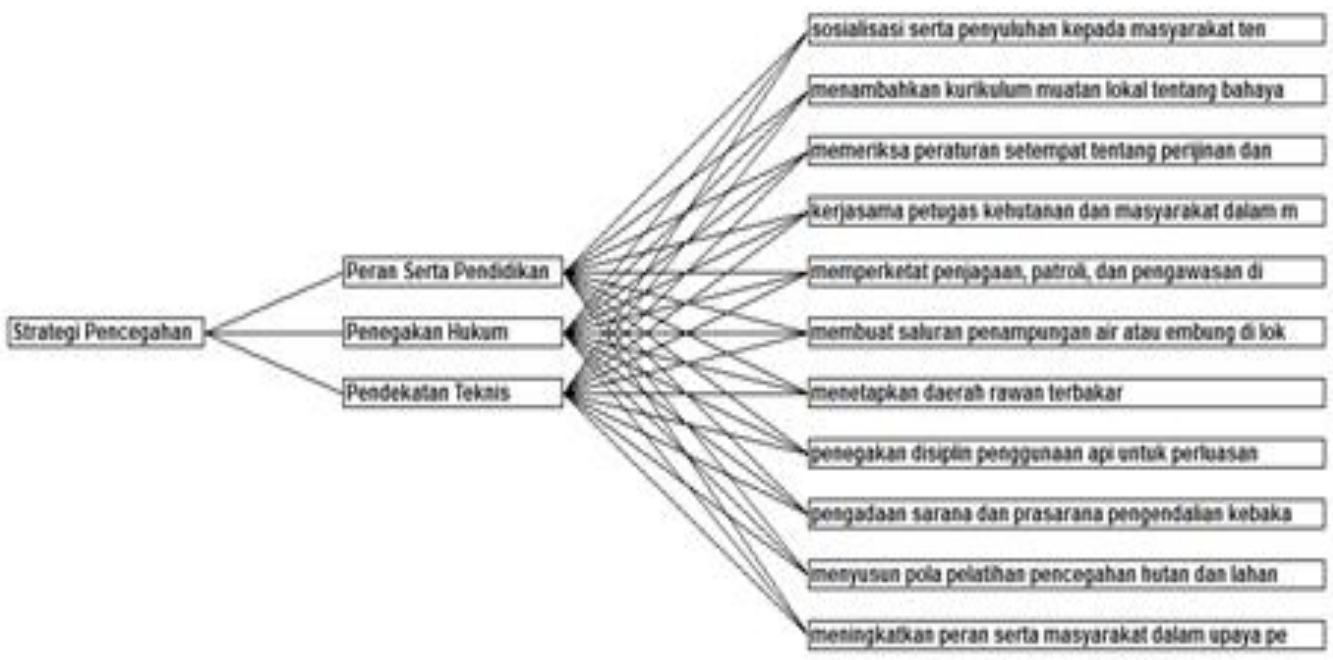

In this study, offered five priorities for policy alternatives offered by the results of discussions with the relevant agencies, namely: 1) impositioning of discipline the use of fire for land expansion, 2) Tightening surveillance, patrols and surveillance in vulnerable forest fire, 3 ) socializing and elucidating to the society about the dangers of forest and land fires, 4) Develop training patterns of forest fire prevention, 5) Establishing areas prone to fire.

Figure 3. Priority directions of policy strategies of forest and fire prevention

\begin{tabular}{|c|c|c|c|}
\hline \multicolumn{4}{|c|}{ Oecion Strog Percepsing } \\
\hline Alienatives & Value & Decision Scores & \\
\hline penegakan ds siplin penggunaan api untuk perfu & 0,834 & & \\
\hline memperketat periagaan, patroli, dan pengawas & 0,806 & & \\
\hline sosialisasi serta peryuldhan kepada masyarak & 0,800 & & \\
\hline menyusun pola pelatihan pencegahan hutan dan & 0,791 & & \\
\hline menetapkan daerah rawan terbakar & 0,782 & & \\
\hline pengadaan sarana dan prasarana pengendalia & 0,729 & & \\
\hline memeriksa peraturan setempat tentang periina & 0,724 & & \\
\hline meningkakan peran serta masyarakat dalam u & 0,718 & & \\
\hline kerjasama petugas kehutanan dan masyarakat & 0,662 & & \\
\hline membuat saluran penampungan air atau embun & 0,653 & & \\
\hline menambahkan kunkulum muatan lokal tentang $b$ & 0,652 & & \\
\hline & 0 & Decienscall & 0,9 \\
\hline
\end{tabular}


Each of these policies will be implemented through the implementation as follows:

1. Enforcement of discipline the use of fire for land expansion

a. Evaluation of the legislation and regulations on the use of fire for land expansion

b. Assertive legal action from the government or related agencies against offenders who do not pass the permitting expansion.

c. Assertive legal action from the government or related agencies against the perpetrators of expansion that does not comply with the law.

d. Setting limits the use of fire for land expansion

2. Tightening guard, patrol and surveillance in vulnerable forest burning

a. Moving the forest officials to further tighten controls on fire-prone areas

b. Reinforce the forestry police performance

3. Socialication and eludication to the society about the dangers of forest fires and land

a. Explaining the causes of forest and land fire

b. Appealing to the public about the dangers of forest and land fire

c. Giving explanation about the direction of prevention of occurrence of a forest fire

4. Prepare the training patterns of forest fire prevention

a. Institutional Strengthening Community Care Fire (MPA)

b. Providing counseling and training the prevention and suppression of forest fire to institute MPA

5. Establish areas prone to fire.

a. Their research on peatland areas and prone to burning

b. Using satellite imagery and GIS system to monitor areas prone to burning

c. Make a map of the area prone to burn and disseminate it to the public forum

\section{Conclusion}

Overall results of the study illustrate that forest fire give many negative impact on the surrounding environment. Government efforts in this regard is already run, but need more leverage policies to restore land damaged by former land and forest fires. In formulating the policy directives of forest fire prevention strategies and land in Belitung Regency can be seen from law enforcement against land and forest fires, technical approach in the prevention of forest fires and land, as well as the role of education in preventing forest and land fire. And results Analytical Hierarchy process (AHP), there are five policy priorities that can be applied to the policy direction of the strategy to prevent forest and land fire in Belitung Regency, namely: 1) imposition of discipline the use of fire for land expansion, 2) Tightening surveillance, patrols and surveillance in vulnerable forest fire, 3) Socialization and eludication to the society about the dangers of forest and land fire, 4) Develop training patterns of forest fire prevention, 5) Establish areas prone to fire. It is needed a support, encouragement and cooperation of the local 
government and community participation in the prevention of forest and land fire in Belitung Regency

\section{REFERENCES}

Bahri, Syamsul. 2002. "Kajian Penyebaran Kabut Asap Kebakaran Hutan dan Lahan di Wilayah Sumatera Bagian Utara dan Kemungkinan Mengatasinya dengan TMC”. Jurnal Sains dan Teknologi Modifikasi Cuaca.

Pasaribu, Sahat M. dan Supena Friyatno. 2006. "Memahami Penyebab Kebakaran Hutan dan Lahan serta Upaya Penanggulangannya: Kasus Di Provinsi Kalimantan Barat”. Jurnal Kebijakan Pertanian. Pusat Analisis Sosial Ekonomi dan Kebijakan Pertanian. Badan Litbang Pertanian, Bogor.

Syaufina, Lailan dan Fransisxo GS Tambunan. 2013. "Kearifan Lokal Masyarakat Adat dalam Pencegahan Kebakaran Hutan dan Lahan (Studi Kasus Masyarakat Adat Kasepuhan Ciptagelar Village of Sirnaresmi, Kecamatan Cisolok, District of Sukabumi, Provinsi Jawa Barat. "Jurnal Silvi kultur Tropika.

Peraturan Kepala Badan Nasional Penanggulangan Bencana No. 2 Tahun 2012 tentang Pedoman Umum Pengkajian Resiko Bencana

Undang-Undang No. 41 Tahun 1999 tentang Kehutanan

Undang-Undang No. 18 Tahun 2004 tentang Perkebunan

Undang-Undang No. 24 Tahun 2007 tentang Penanggulangan Bencana 